\section{International Scientific Journal Theoretical \& Applied Science}

p-ISSN: 2308-4944 (print) e-ISSN: 2409-0085 (online)

Year: $2016 \quad$ Issue: $5 \quad$ Volume: 37

Published: $30.05 .2016 \quad$ http://T-Science.org

SECTION 9. Chemistry and chemical technology.
Khadija Nizami qizi Mammadyarova Azerbaijan National Academy of Sciences Academician A.M.Guliyev Institute of Chemistry of Chemistry of Additives, scientific collaborator xedice.memmedyarova@mail.ru

Ali Kazim oglu Kazimzadeh

Azerbaijan National Academy of Sciences Academician A.M.Guliyev Institute of Chemistry of Additives, doctor of chemical Sciences, professor aki05@mail.ru

Elmira Ali gizi Nagiyeva Azerbaijan National Academy of Sciences Academician A.M.Guliyev Institute of Chemistry of Additives, doctor of technical Scienes, associate professor Nagiyeva1946@mail.ru

Ali Ashraf oglu Gadirov Azerbaijan National Academy of Sciences Academician A.M.Guliyev Institute of Chemistry of Chemistry of Additives, $\mathrm{PhD}$ in Chemistry, associate professor gadirov58@mail.ru

Sakhila Ikram gizi Nasirova Azerbaijan National Academy of Sciences Academician A.M.Guliyev Institute of Chemistry of Additives, engineer aki05@mail.ru

\title{
MODIFIED MULTIFUNCTIONAL ALKYLPHENOLATE ADDITIVES TO MOTOR OILS
}

Abstract: The results of research by synthesis of the new ИХП-144 and ИХП-154 sulphuric alkylphenolate additives are given on this article. ИХП-144 additive consists of calcium salt of condensation product with alkylphenol, formaldehyde and sodium sulfide and ИХП-154 is its carbonated variant. Offered additives is obtained by simplified technology and with energy saving. High exploitation gualities of additives ИХП-144 and ИХП-154 allow to use its for developing modern motor oils.

Key words: additive, alkylphenol, formaldehyde, sodium sulfide, motor oil.

Language: English

Citation: Mammadyarova KN, Kazimzadeh AK, Nagiyeva EA, Gadirov AA, Nasirova SI (2016) MODIFIED MULTIFUNCTIONAL ALKYLPHENOLATE ADDITIVES TO MOTOR OILS. ISJ Theoretical \& Applied Science, 05 (37): 29-31.

Soi: http://s-o-i.org/1.1/TAS-05-37-6

Doi: crossef http://dx.doi.org/10.15863/TAS.2016.05.37.6

In worldwide practice the sulfur-bearing alkylphenol additives for motor oils are widespread. ВНИИНП-714, ОЛОА-218А, АМОКО-9230 and others are those type of additives [5-7].

Currently in creating high-performance lubricating oils the organic sulfur compounds received widespread occurance[1-4]

Upon receipt of these additives the sulfiding stage is carried out using elemental sulfur at 170 $190^{\circ} \mathrm{C}$ and with hydrogen sulfide discharge.
We have proposed a method of producing sulfur-containing alkylphenol additives where the sulfiding stage is carried out using sodium sulfide [8].

The process of obtaining an additive differs by energy saving, and environmentally-friendly technology (sulfiding is carried out without releasing of hydrogen sulfide at a temperature of $95-98^{\circ} \mathrm{C}$ ).

Obtained additive AKI-144 is the calcium salt of di ( alkylxibenzyl) sulfide.

The main stages of additive synthesis are: 


\begin{tabular}{|c|c|c|c|c|c|c|}
\hline Impact Factor: & $\begin{array}{l}\text { ISRA (India) } \\
\text { ISI (Dubai, UAE } \\
\text { GIF (Australia) } \\
\text { JIF }\end{array}$ & $\begin{array}{l}=1.344 \\
=0.829 \\
=0.564 \\
=1.500\end{array}$ & $\begin{array}{l}\text { SIS (USA) } \\
\text { PИНЦ (Russia) } \\
\text { ESJI (KZ) } \\
\text { SJIF (Morocco) }\end{array}$ & $\begin{array}{l}=0.912 \\
=0.234 \\
=1.042 \\
=2.031\end{array}$ & $\begin{array}{l}\text { ICV (Poland) } \\
\text { PIF (India) } \\
\text { IBI (India) }\end{array}$ & $\begin{array}{l}=6.630 \\
=1.940 \\
=4.260\end{array}$ \\
\hline
\end{tabular}

- condensing of alkyl phenol with formaldehyde and sodium sulfide;

- neutralizing the condensation product of the calcium hydroxide;
- drying and centrifuging (separation of solids) of neutralization products.

Project scheme of the reaction:

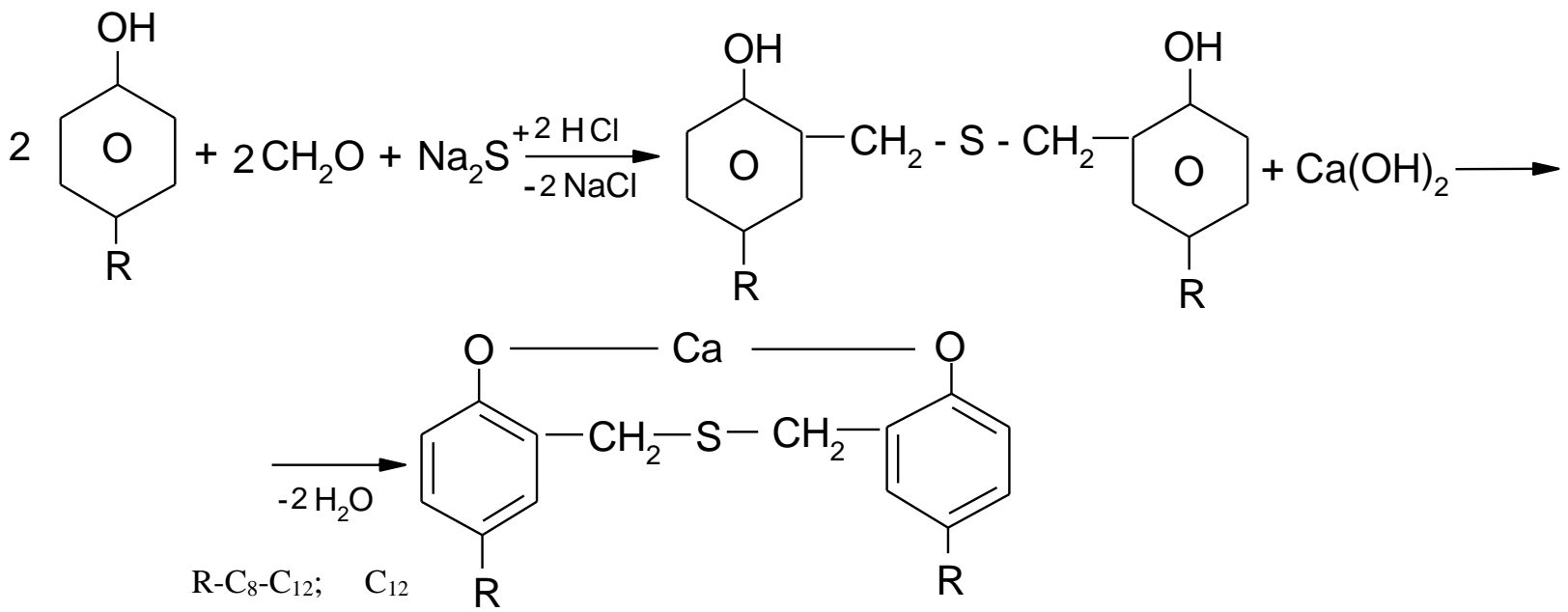

The optimal conditions for producing AKI-144 additive were found and their physico-chemical and functional properties were studied. Physico-chemical and functional properties of AKI-144 additives samples in comparison with ЦИАТИМ-339 (barium sulfide alkylphenolate) additive are listed on table 1 .

As it is shown in tab.1 AKI-144 additive is superior to ЦИАТИМ-339 additive by anticorrosive, anti- oxidative and purifying properties.

The presence in the additive of the benzyl groups instead of phenyl apparently imparts higher performance characteristics than ЦИАТИМ-339 additive.

One of the ways to improve the operating abilities of additives is to increase the alkalinity[9].
The second additive AKI-154 as an overbased option for AKI-144 additive has been obtained[10].

Base number is one of the most important indicators of neutralizing abilities of oils as well as certain detergents which in turn leads to increased corrosion, antioxidant, neutralizing and detergency additives.

Carbonation conditions of AKI-154 additive:

calcium hydroxide $40 \%$ ( on alkylphenol), carbonation temperature $85^{\circ} \mathrm{C}$, time of carbon dioxide supply is 4,5 hours.

$5 \%$ glycerol was used as a promoter.

Suggested reaction scheme:

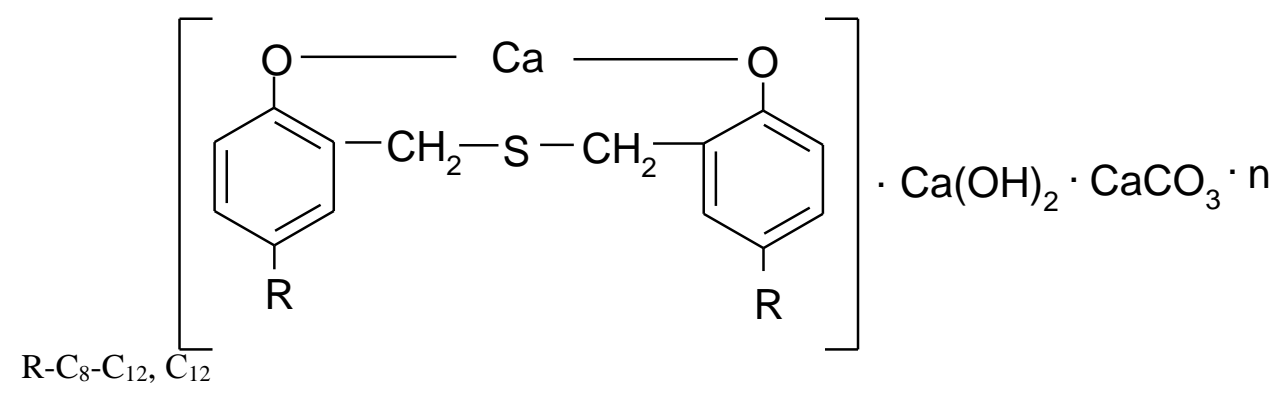

Physico-chemical and functional properties of the additive AKI-154 and the test results of compared commodity additives ВНИИНП-714 and ОЛОА-218A are also listed in a table.

The tests were conducted according to the following standard methods:

- anticorrosion properties (ГОСТ 20502-75);

- stability of the induction period of sedimentation (ГOCT 11063-77);

- cleaning properties of PZV (ГОСТ 5226-
Studies have shown that the AKI-154 additive by detergent-dispersant, anti-oxidation, anticorrosion properties are superior to AKI-144 additive, by anticorrosion properties to ВНИИНП714 and ОЛОА-218А, and by detergent-dispersant and antioxidant properties equivalent to foreign analogues.

Thus, superior performance additives allow to use them for the development of advanced engine oils. 2013). 


\begin{tabular}{l|lrl|l|ll} 
& ISRA (India) & $=\mathbf{1 . 3 4 4}$ & SIS (USA) & $=\mathbf{0 . 9 1 2}$ & ICV (Poland) & $=\mathbf{6 . 6 3 0}$ \\
Impact Factor: & ISI (Dubai, UAE) $=\mathbf{0 . 8 2 9}$ & PUHU (Russia) $=\mathbf{0 . 2 3 4}$ & PIF (India) & $=\mathbf{1 . 9 4 0}$ \\
& GIF (Australia) & $\mathbf{0 . 5 6 4}$ & ESJI (KZ) & $=\mathbf{1 . 0 4 2}$ & IBI (India) & $\mathbf{4 . 2 6 0}$
\end{tabular}

Physico-chemical and functional properties of additives.

Table 1

\begin{tabular}{|c|c|c|c|c|c|c|}
\hline \multirow[b]{2}{*}{ № } & \multirow[b]{2}{*}{ Additives } & \multirow[b]{2}{*}{$\begin{array}{l}\text { Alkaline } \\
\text { number, } \\
\text { mgKON/g }\end{array}$} & \multirow[b]{2}{*}{$\begin{array}{c}\text { Ash } \\
\text { sulfonate, } \%\end{array}$} & \multicolumn{3}{|c|}{ M-8 oil from 5\% additive } \\
\hline & & & & $\begin{array}{l}\text { Corrosivity } \\
\text { on the plates of } \\
\text { lead, } \mathrm{g} / \mathrm{m}^{2}\end{array}$ & $\begin{array}{c}\text { Induction } \\
\text { Precipitation } \\
\text { period of } \\
\text { education } \\
\text { stability, 30h. } \\
\text { sediment, \% }\end{array}$ & $\begin{array}{l}\text { Cleaning } \\
\text { properties } \\
\text { PZV, score }\end{array}$ \\
\hline 1. & AKI-144 & 70.1 & 6.95 & 4.8 & 1.0 & $0.5-1.0$ \\
\hline 2. & AKİ-144 & 78.4 & 7.8 & 1.8 & 0.8 & $0.5-1.0$ \\
\hline 3. & ЦИАТИМ-339 & 42.0 & 10.3 & 30.4 & 5.2 & $1.0-1.5$ \\
\hline 4. & AKI-154 & 150.1 & 15.2 & 1.4 & abs. & $0-0.5$ \\
\hline 5. & ВНИИНП-714 & 143.0 & 15.5 & 5.2 & abs. & 0.5 \\
\hline 6. & ОЛОА-218А & 140.0 & 17.6 & 9.6 & abs. & 0.5 \\
\hline
\end{tabular}

AKİ-144 - №1 obtained on the basis of an alkylphenol, wherein R-C8-C12;

AKİ-144 - №2 obtained based on an alkylphenol, where R-C12.

\section{References:}

1. Kirpichenko TN, Desyatkin AA, Ibrahimov AQ, Gamilov UM (2009) Journal of Applied Chemistry-2009. T-82.-no.1. pp.94-98.

2. Ryazancev NK, Borodin YS, Bichkov VZ, et al. (2002) - XTTM. -no.5. pp. 21-22.

3. (1985) Pat. №219189QDR.1985.

4. Mammedbeyli EQ, Djafarov IA, Kochetkov KA, Kazimova TQ, Hasanov XI, Mammadova IM (2011) Oil chemistry-2011.T.51, no.6, pp.477-480.

5. Selezneva EA, Levin AY, Monin SV (1999) XTTM - 1999. no.6. - pp.39-43.
6. Selezneva EA, Levin AY, Trofimov QL, Ivanova OV, Budanovskaya QA (2009) New overbased alkylphenolate additives to motor oils. XTTM-2009-no.4.pp.10-12.

7. Borshevskiy SB, Ivankovskiy VL, Tushin LA, Rojdestvina OV (2007) Chemistry and technology of oil and fuel.-2007.no.6.pp.36-38.

8. (2006) Pat.Az. Rep. №20060082

9. Lashxi VL, Leymeter T, Shor QI, Falkovich MI (2001) Chemistry and technology of oil and fuel-2001.no.5, pp.49-51.

10. (2011) Pat.Az. Rep. №20110024 